\title{
Effect of in vivo administration of an antibody to epidermal growth factor on the rapid increase in DNA synthesis induced by partial hepatectomy in the rat
}

\author{
D A Vesey, A C Selden, A C Woodman, H J F Hodgson
}

\begin{abstract}
Recent reports indicate that transforming growth factor alpha (TGF- $\alpha$ ) is produced within the liver and acts as the natural ligand of the epidermal growth factor (EGF) receptor causing the EGF receptor down regulation and the hepatocyte proliferation observed after partial hepatectomy. The reported phenomenon that an antibody to EGF inhibits the regenerative response to partial hepatectomy was therefore re-investigated. The IgG fraction of an anti-rat EGF antibody was injected intravenously at the time of partial hepatectomy, and its effects on regenerative DNA synthesis were compared with those of nonimmune IgG. Injection of IgG reduced the DNA synthetic response to partial hepatectomy, assessed 24 hours after resection by ${ }^{3} \mathrm{H}$-thymidine incorporation, but the effects of normal and anti-EGF IgG were not statistically different, despite the presence of excess antiEGF IgG in the circulation throughout the experimental period. However, anti-EGF IgG could completely block the proliferative response of hepatocytes in culture to EGF. These results support the suggestion that EGF is not the major mediator of hepatocyte DNA synthesis in the early stages of liver regeneration ( $<24$ hours).
\end{abstract}

The factors controlling hepatic regeneration after partial hepatectomy are complex. ${ }^{\prime}$ Recent years have seen the description of a number of growth factors, generated in the liver or present in the circulation after partial hepatectomy, which in in vitro studies have the ability to enhance DNA synthesis in hepatocytes. ${ }^{2}$ These include hepatotropin (also known as hepatocyte growth factor (HGF) or hepatopoietin A, reported in both man and rat), ${ }^{3-5}$ heparin binding growth factor $-1,{ }^{6}$ transforming growth factor $\alpha$ (TGF- $\alpha),{ }^{7}$ hepatic stimulator substance (HSS), ${ }^{8}$ and hepatopoietin B. ${ }^{9}$

Description of these growth factors has led to a re-evaluation of the in vivo role of epidermal growth factor (EGF), a powerful in vitro mitogen for hepatocytes. ${ }^{10}$ Studies over a number of years promoted the concept that EGF acts as an initiator of hepatocyte DNA synthesis after partial hepatectomy. Evidence was based on the striking demonstration of rapid down regulation of the EGF receptor during the proliferative process in vivo, ${ }^{11}$ and the fact that in in vitro studies, down regulation of the receptor after exposure of hepatocytes to EGF leads to a series of intracellular events culminating in DNA. ${ }^{12} 13$ Furthermore, infusion of labelled EGF at the time of partial hepatectomy is followed by EGF uptake into liver cells via this receptor, in predominantly perilobular areas of the liver where proliferation is most evident, ${ }^{1+16}$ and within six hours enhanced amounts of EGF are found in the nucleus of hepatocytes. ${ }^{17}$ However, evidence for a significant enhancement of circulating EGF levels after partial hepatectomy is lacking, and EGF is not generated within the liver itself. ${ }^{18-20}$ These paradoxes were apparently resolved by the finding that TGF- $\alpha$, which has extensive structural homology with EGF, is expressed within the liver in enhanced amounts a few hours after partial hepatectomy, binds to the EGF receptor, and can initiate EGF receptor down regulation and DNA synthesis. ${ }^{721}$ TGF- $\alpha$ may therefore be the natural ligand for the EGF receptor at this time. If this is so, the observation that an antibody to EGF, administered at the time of partial hepatectomy in rats, was reported to be associated with a reduced regenerative response, ${ }^{19}$ requires examination. We therefore investigated the effect of administering an antibody to EGF at the time of partial hepatectomy in rats.

As administration of exogenous protein at the time of partial hepatectomy has been noted to reduce the proliferative response of the liver to partial hepatectomy, ${ }^{22}$ we tested the hypothesis that there would be no difference between the effect of a preparation of IgG containing antiEGF antibody and a preparation of non-specific IgG. We measured the effect of these preparations on DNA synthesis at the time of peak replicative activity 24 hours after partial hepatectomy.

The changes in EGF receptor numbers 24 hours after partial hepatectomy are large - a $50-90 \%$ reduction. ${ }^{721}$ Blocking the putative effect of EGF in initiating this receptor down regulation might therefore be expected to have a substantial effect on DNA synthesis, if EGF is in 
fact the major stimulus to regeneration at this time.

\section{Methods}

[6- $\left.{ }^{3} \mathrm{H}\right]$-thymidine (specific activity $25-30 \mathrm{Ci} /$ mmol) and carrier free $\mathrm{Na}^{125} \mathrm{I}$ were obtained from Amersham International PLC, Bucks, UK. Williams' medium E, fetal bovine serum (FBS), penicillin/streptomycin, fungizone (amphotericin B), gentamycin, Freund's adjuvant, and Nunclon microwell plates were obtained from Gibco, Renfrewshire, Scotland. Insulin (Human monocomponent, Actrapid) was purchased from Novo, Copenhagen, Denmark. Collagenase (Clostridium histolyticum) was purchased from Boehringer Mannheim (UK) Ltd, East Sussex, UK. Other reagents and chemicals were from Sigma Chemical Company or BDH Chemicals, Dorset, UK. Collaborative Research mouse EGF (tissue culture grade) was obtained from Universal Biologicals, London, UK.

All experiments were performed on male August rats $(250-300 \mathrm{~g})$ supplied by the National Institute of Medical Research, Mill Hill, London, UK, which had free access to food and water.

\section{EXPERIMENTAL DESIGN}

A $70 \%$ hepatectomy was performed as described by Higgins and Anderson..$^{23}$ One $\mathrm{ml}$ of purified IgG fraction ( $3 \mathrm{mg}$ ) from either normal rabbit serum or rat EGF immunised rabbit serum was injected into rats via the jugular vein at time of hepatectomy. All procedures were carried out under ether anaesthetic between 9 and 11 am. Four groups of five animals were studied. The treatments were as follows:

Group 1: partial hepatectomy plus nonimmune IgG.

Group 2: partial hepatectomy plus anti-rat EGF IgG.

Group 3: sham operation (liver palpation and an incision at site of IgG administration).

Group 4: partial hepatectomy alone.

Twenty three hours postoperatively all rats received an intraperitoneal injection of ${ }^{3} \mathrm{H}$-thymidine $(0.5 \mu \mathrm{Ci} / \mathrm{g}$ body weight $)$. Rats were killed one hour later by exsanguination under ether, and the livers were rapidly removed. A section of liver tissue was formalin fixed for histology and the remainder frozen for measurement of thymidine incorporation. Blood was allowed to clot at $10^{\circ} \mathrm{C}$ for 4 hours, serum separated, and stored at $-20^{\circ} \mathrm{C}$.

\section{EGF PURIFICATION AND IODINATION}

EGF was purified from rat submandibular glands as described by Moore ${ }^{24}$ and iodinated using Chloramine-T. EGF $(10 \mu \mathrm{g})$ in $50 \mu \mathrm{l}$ of $0.4 \mathrm{~mol} / \mathrm{l}$ sodium phosphate buffer, $\mathrm{pH} 7 \cdot 6$, was combined with $0.5 \mathrm{mCi}$ (in $5 \mu \mathrm{l}$ ) of carrier-free $\mathrm{Na}^{125}$. Chloramine-T $(5 \mu \mathrm{g}$ in $10 \mu \mathrm{l}$ of $0.04 \mathrm{~mol} / \mathrm{l}$ sodium phosphate buffer) was added and mixed for 14 seconds at room temperature. The reaction was terminated by the addition of sodium metabisulphite $(25 \mu \mathrm{g}$ in $100 \mu \mathrm{l}$ of 0.04 $\mathrm{mol} / \mathrm{l}$ buffer) and sodium iodide $(100 \mu \mathrm{g}$ in $50 \mu \mathrm{l}$ of water). This mixture was then diluted with $115 \mu \mathrm{l}$ of $0.04 \mathrm{~mol} / \mathrm{l}$ phosphate buffer containing $10 \%$ sucrose. ${ }^{125}$ I labelled EGF was separated from free ${ }^{125} \mathrm{I}$ by gel filtration on a Sephadex G50 superfine column $(1 \cdot 1 \times 32 \mathrm{~cm})$ in phosphate/ EDTA buffer containing BSA $(54 \mathrm{mmol} / 1$ $\mathrm{Na}_{2} \mathrm{HPO}_{4} .2 \mathrm{H}_{2} \mathrm{O}, 7 \mathrm{mmol} / 1 \mathrm{KH}_{2} \mathrm{PO}_{4}, 10 \mathrm{mmol} / 1$ EDTA, 0.3\% (w/v) BSA, pH 7-2). ${ }^{125}$ I-EGF was stored at $-20^{\circ} \mathrm{C}$. The specific antibody of the ${ }^{125} \mathrm{I}-\mathrm{EGF}$ obtained in this way was $30 \mu \mathrm{Ci} / \mu \mathrm{g}$.

\section{ANTIBODY PRODUCTION}

A rat EGF antibody was raised in a Half-lop female rabbit. Purified rat EGF $(120 \mu \mathrm{g})$ in complete Freund's adjuvant was given by five intradermal injections in the back. A booster injection of $80 \mu \mathrm{g}$ of rat EGF in incomplete Freund's adjuvant was given after two weeks. Subsequent booster injections were at four week intervals. Blood $(20 \mathrm{ml})$ was obtained from the marginal ear vein 10 days after each boost injection, the serum was separated and stored in aliquots at $-20^{\circ} \mathrm{C}$.

\section{PURIFICATION OF SERUM IGG}

Protein A-sepharose (CL-4B) affinity chromatography was used to purify anti-rat EGF IgG from serum obtained after the fourth booster injection and non-specific IgG from non-immune rabbit serum. In brief, $2 \mathrm{ml}$ of serum, diluted 1:1 with PBS were passed twice through a small protein A-sepharose column (pre-equilibrated in $10 \mathrm{mmol} / \mathrm{l}$ Tris buffer containing $0.12 \mathrm{~mol} / \mathrm{l}$ $\mathrm{NaCl} \mathrm{pH} \mathrm{7.4)} \mathrm{and} \mathrm{the} \mathrm{column} \mathrm{washed} \mathrm{with} 10$ column volumes of Tris buffer. IgG was eluted in $3 \times 2.5 \mathrm{ml}$ fractions with $1 \%(\mathrm{v} / \mathrm{v})$ acetic acid, the fractions were neutralised with $1.5 \mathrm{~mol} / \mathrm{l}$ unbuffered Tris, and the absorbance at $280 \mathrm{~nm}$ was measured. The IgG containing fraction $(2.8 \mathrm{ml})$ was desalted on a prepacked Sephadex G50 column (PD10, LKB-Pharmacia) and equilibrated in PBS. Protein was determined by the modified method of Lowry with BSA as a standard. ${ }^{25}$ Purified IgG in PBS was filter sterilised and stored at $4^{\circ} \mathrm{C}$ until used. The possibility of cross reaction between the antiEGF antibody and TGF- $\alpha$ was explored by investigating binding of radiolabelled h-r-TGF- $\alpha$ (kindly donated by Dr W J Gullick) but no binding was detected.

\section{CELL CULTURE}

Hepatocytes were isolated from normal young adult August rats (NIMR, Mill Hill) by an in situ collagenase perfusion similar to the method of Berry and Friend. ${ }^{26}$ Cell viability, assessed by the ability to exclude trypan blue $(0 \cdot 2 \%)$, was $>80 \%$. Cells were resuspended in Williams' medium $\mathrm{E}$ w/o L-glutamine, containing penicillin $(200 \mathrm{IU} / \mathrm{ml})$; streptomycin $(200 \mathrm{IU} / \mathrm{ml})$; gentamycin $(80 \mu \mathrm{g} / \mathrm{ml})$; fungizone $(1.25 \mu \mathrm{g} / \mathrm{ml})$; $5 \%(\mathrm{v} / \mathrm{v})$ heat inactivated fetal bovine serum, and dexamethazone $\left(10^{-8} \mathrm{~mol} / \mathrm{l}\right)$ (plating medium) at $2 \times 10^{5}$ viable cells per $\mathrm{ml}$ and seeded into collagen coated (rat-tail collagen, type 1) 96 well Nunclon tissue culture plates $(100 \mu \mathrm{l} /$ well $)$. 
Cells were maintained at $37^{\circ} \mathrm{C}$ in an atmosphere of air $/ \mathrm{CO}_{2}$ (19:1) with $>95 \%$ humidity.

\section{ASSESSMENT OF DNA REPLICATION}

\section{In vitro}

DNA synthesis was measured by assessment of $\left[{ }^{3} \mathrm{H}\right]$-thymidine incorporation into cell DNA. Twenty hours after seeding, the medium was changed and replaced with either plating medium alone or plating medium containing insulin $\left(10^{-7} \mathrm{~mol} / \mathrm{l}\right)$, with or without rat EGF $(10 \mathrm{ng} / \mathrm{ml})$. To test whether the purified anti-rat EGF IgG blocked the proliferative response of the hepatocytes to EGF, DNA synthesis was assessed in the presence of a 1:50 dilution of anti-EGF IgG. ${ }^{3} \mathrm{H}$-thymidine $(2 \mu \mathrm{Ci} /$ well $)$ was included in the cultures from 28 hours after plating. The amount of ${ }^{3} \mathrm{H}$-thymidine incorporated was assessed as described by Selden and Hodgson ${ }^{27}$ between 44 and 48 hours after seeding. Samples were assayed in quadruplicate.

\section{In vivo}

${ }^{3} \mathrm{H}$-thymidine incorporation into liver DNA was measured biochemically by a modification of the method of Munro and Fleck 1966..$^{28} \operatorname{Liver}(0 \cdot 4 \mathrm{~g})$ was homogenised in $5 \mathrm{ml}$ of ice cold $5 \mathrm{mmol} / \mathrm{l}$ Hepes buffer $\mathrm{pH} 7.5$ for 30 seconds with a Potter-Elvehjem homogeniser. The homogenate was precipitated with $5 \mathrm{ml}$ of ice cold $0.6 \mathrm{mmol} / \mathrm{l}$ perchloric acid for 10 minutes on ice. This was centrifuged at $1500 \mathrm{~g}$ for 20 minutes and the pellet washed twice with $0.2 \mathrm{mmol} / 1$ perchloric acid by repeated homogenisation and centrifugation. After the final wash, the pellet was drained, solubilised in $4 \mathrm{ml} 0.3 \mathrm{mmol} / 1 \mathrm{KOH}$, and incubated for 1.5 hours in a $37^{\circ} \mathrm{C}$ water bath. Samples were cooled on ice for 10 minutes and re-precipitated in $4 \mathrm{ml}$ of $1.2 \mathrm{mmol} / \mathrm{l}$ perchloric acid. The pellet was washed twice with 0.2 $\mathrm{mmol} / \mathrm{l}$ perchloric acid and the final DNA pellet was hydrolysed by heating at $80^{\circ} \mathrm{C}$ for 20 minutes in $4 \mathrm{ml}$ of $0.5 \mathrm{mmol} / \mathrm{l}$ perchloric acid. Fifty $\mu \mathrm{l}$ of supernatant were counted for tritium in $1 \mathrm{ml}$ of Optiphase safe scintillant (Pharmacia-LKB).

\section{AUTORADIOGRAPHY}

Autoradiography was used to assess the proportion of hepatocytes which had entered DNA synthesis. This analysis was performed on coded samples, without knowledge of the experimental protocol undergone by each animal before death. For technical reasons this analysis was performed in only 4 of the 5 livers from animals receiving normal $\operatorname{IgG}$, but in all 5 animals receiving anti-EGF IgG.

Sections $5 \mu \mathrm{m}$ were cut from formalin fixed paraffin embedded samples of regenerating liver and 'taken down' to water. Slides were dipped into Ilgard $\mathrm{k} 5$ nuclear emulsion diluted 1:2(v/v) with $0.02 \%$ glycerol in distilled water, and exposed for three weeks at $4^{\circ} \mathrm{C}$ in the dark. After developing, using Kodak D19 developer and Amifix fixer (May \& Baker), sections were counterstained with haematoxylin and eosin and the labelling index for each treatment was
Effect of anti-epidermal growth factor $(E G F) \operatorname{Ig} G$ on liver DNA synthesis after partial hepatectomy. ${ }^{3} H$-thymidine incorporation in rat liver 24 hours after partial hepatectomy, sham operation, or partial hepatectomy plus EGF specific IgG or non-specific IgG injections. (Data mean (SEM) for determinations in the 5 animals.)

\begin{tabular}{lll}
\hline Treatment & $\begin{array}{c}\text { 'H-thymidine incorporation } \\
\left(d p m \times 10^{4} / g \text { liver }\right)\end{array}$ & No \\
\hline Hepatectomy & $541 \cdot 1(26 \cdot 6)$ & 5 \\
Sham & $9 \cdot 4(1 \cdot 2)$ & 5 \\
Hepatectomy+ & $388 \quad(21 \cdot 7)$ & 5 \\
$\begin{array}{c}\text { anti-EGF IgG } \\
\text { Hepatectomy+ } \\
\text { non-immune IgG }\end{array}$ & $413 \quad(44 \cdot 9)$ & 5 \\
\hline
\end{tabular}

assessed by scoring 3000 randomly selected morphologically distinct hepatocytes.

\section{BINDING CAPACITY OF SERUM}

Serum from rats at death was assayed for anti-rat EGF IgG. One hundred $\mu$ of suitably diluted serum $\left(1: 10-1 \times 10^{+}\right)$were mixed with $1800 \mathrm{cpm}$ of ${ }^{125}$ I-rat EGF $(100 \mu \mathrm{l})$ in a total volume of $0.8 \mathrm{ml}$ phosphate/EDTA buffer and incubated at $10^{\circ} \mathrm{C}$ for four days. Antibody bound label was separated from free label by charcoal (Norit GSX, BDH) precipitation. Then $200 \mu \mathrm{l}$ of charcoal $(32 \mathrm{mg} / \mathrm{ml})$ dissolved in phosphate/ EDTA buffer containing dextran $(3 \cdot 2 \mathrm{mg} / \mathrm{ml})$ were added to each tube and tubes centrifuged $(1500 \mathrm{~g})$ at $4^{\circ} \mathrm{C}$ for 20 minutes. Separated pellet and supernatant were counted in a gamma counter.

\section{STATISTICAL METHODS}

Comparisons between groups were made using Student's unpaired $t$ test. Pilot experiments had indicated that the antibody to EGF was capable of entirely abrogating the response to EGF in vitro; analysis of other preliminary experiments demonstrated that in the presence of non-specific IgG, regenerating liver incorporated about $400000 \mathrm{dpm} / \mathrm{g}$. It was postulated that if EGF was the major mediator of the regenerative process, the anti-EGF IgG would reduce this by at least $200000 \mathrm{dpm}$. From previous studies on the variability of the response to hepatectomy, it was estimated that this difference could be detected with power $>95 \%$ by comparing means of groups of 5 animals using a $t$ test.

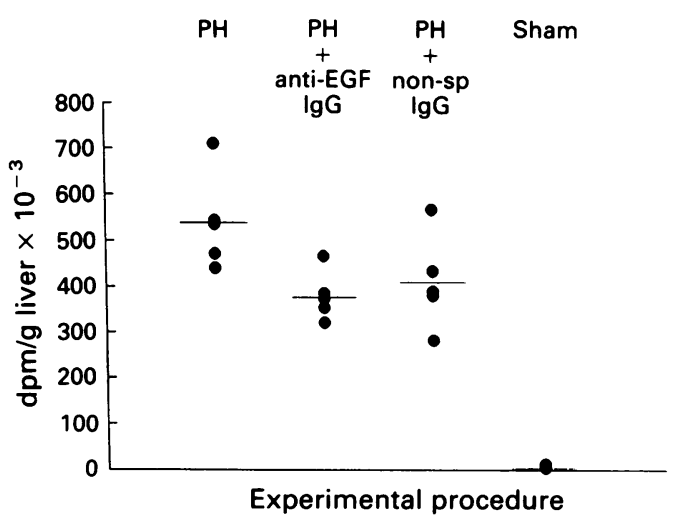

Figure 1: Individual data points for ${ }^{3} \mathrm{H}$-thymidine incorporation into liver 24 hours after partial hepatectomy $(P H)$, alone, with anti-epidermal growth factor IgG, normal IgG, or sham operation. 


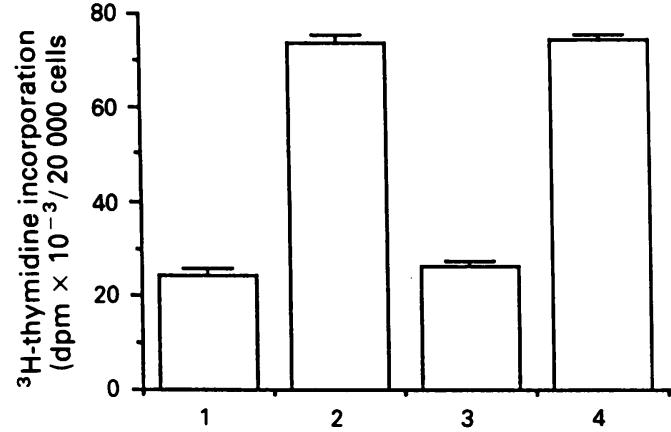

Figure 2: Effect of anti-epidermal growth factor (EGF) IgG and non-specific IgG (1:50 dilution) on the response of primary hepatocytes to $10 \mathrm{ng} / \mathrm{ml}$ EGF. Column 1: no EGF; column 2: $10 \mathrm{ng} / \mathrm{ml}$ EGF; column 3: EGF plus anti-EGF IgG; column 4: EGF plus non-immune IgG. All cultures contained dexamethazone $\left(10^{-8} \mathrm{mmol} / \mathrm{l}\right)$ and insulin $10^{-7} \mathrm{mmol} / \mathrm{l}$.

(Results are the mean $(S D)$ of quadruplicate

measurements from a typical experiment. $n=3$.)

\section{Results}

\section{LIVER DNA SYNTHESIS IN VIVO}

Twenty four hours after partial hepatectomy, there was an approximately 60 fold increase in ${ }^{3} \mathrm{H}$-thymidine incorporation compared to the liver of sham operated rats (Table I). Rats receiving $1 \mathrm{ml}$ of purified anti-EGF IgG by intravenous injection at the time of partial hepatectomy had a smaller increase in specific tritiated thymidine incorporation, as did rats receiving non-specific IgG (Fig 1). In both groups of animals receiving IgG, there was a substantial reduction in thymidine incorporation compared with control animals $(\mathrm{p}<0.001$ in each case). The difference between the two groups of animals receiving either specific or non-specific IgG was small and not statistically significant (difference between means $=-25000 \mathrm{dpm} / \mathrm{g}$; $95 \% \mathrm{CI}-140000$ to $+9000 \mathrm{dpm} / \mathrm{g}$ ).

To confirm the similarity of the magnitude of the regenerative process occuring in the two groups of animals that received IgG, autoradiographs were performed and the proportion of hepatocyte nuclei showing accumulation of radioactive thymidine counted. Again there was no statistically significant difference between the percentage of labelled cells in the two groups (Anti-EGF group, mean (SEM) $22 \cdot 8(2 \cdot 7) \%$ cells labelled, cf non-specific IgG group, $27 \cdot 2$ $(3 \cdot 55) \%$ labelled; $p=0 \cdot 176, \mathrm{NS})$.

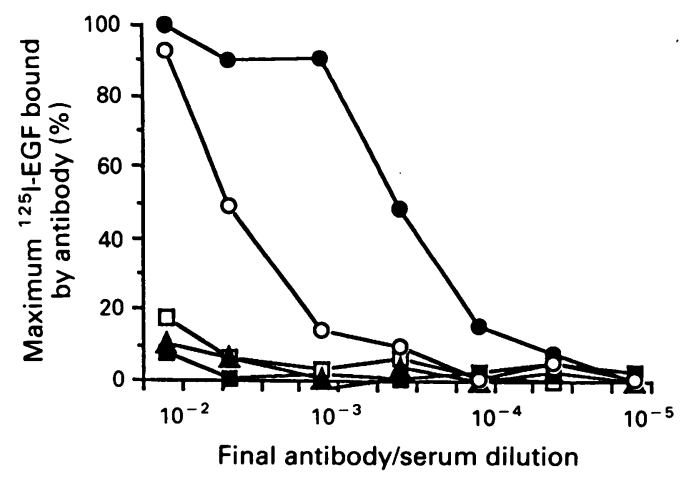

Figure 3: Binding of ${ }^{125}$ I labelled epidermal growth factor $(E G F)$ by dilutions of anti-epidermal growth factor I $g(O)$ non-immune IgG (D) and serum from animals who had received immune (O), non-immune (A) or no IgG ( $\square$ ) 24 hours after hepatectomy.

\section{HEPATOCYTE DNA SYNTHESIS IN VITRO}

To confirm the inhibitory effect of the anti-EGF antibody on EGF mediated hepatocyte replication, primary cultures of rat hepatocytes were stimulated with optimal concentrations of EGF $(10 \mathrm{ng} / \mathrm{ml})$ in the presence of dexamethasone, the cofactor insulin, and dilutions of anti-EGF IgG or non-immune IgG. Dilutions of 1:50 of antiEGF IgG completely blocked the proliferative response to EGF (Fig 2) but had no effect on the proliferative response to TGF- $\alpha$ (data not shown). Non-immune IgG was also without effect on the response to either EGF or TGF- $\alpha$.

\section{PRESENCE OF ANTI-EGF IGG IN RAT SERUM}

The EGF binding capacity of the serum from rats who had received anti-EGF antibody was assessed at the time of death 24 hours after partial hepatectomy. Figure 3 shows the EGF binding capacity of anti-EGF IgG administered, and the mean binding of serum from two animals who received this antibody. For comparison the EGF binding capacity of the IgG fraction of nonimmune serum and the mean binding of serum from two animals who received this is shown. Substantial binding capacity for EGF was retained within the animals who had received anti-EGF IgG 24 hours beforehand.

\section{Discussion}

Unlike Skov Olsen et $a l,{ }^{19}$ we were not able to detect a reduction in the proliferative response induced by partial hepatectomy when animals were given an antibody to rat EGF. The antibody was capable of inhibiting the in vitro response of hepatocytes to EGF, and EGF binding capacity persisted in the circulation throughout the 24 hours after partial hepatectomy. There are a number of methodological differences between our procedure and that of Skov Olsen et al. ${ }^{19}$ The most striking is that their report of the inhibitory effects of anti-EGF antibody was compiled from an estimation of total hepatic DNA five days after resection, rather than from the proliferative response initiated within 24 hours of resection. We felt that the immediate response was more relevant, as the physiological effects involving the EGF receptor are most noticeable within the first 24 hours of partial hepatectomy.

By five days, many factors can affect the regenerative response of the liver, including metabolic factors such as protein and fat intake. ${ }^{29}{ }^{30}$ It is indeed possible that at a period between 24 hours (at which time point our results suggest EGF is not relevant to modulation of EGF receptor concentration and DNA synthesis) and the five day interval investigated by Skov Olsen, EGF does act to modulate the regenerative response. The evidence indicating that duodenectomy, which removes a major source of EGF from Brunner's glands, also diminishes the five day response to partial hepatectomy, favours this. The rapid fall in EGF receptor expression that occurs within four hours and persists for at least 24 hours after partial hepatectomy may be followed by re-expression of receptors during the next four days. Combination of these re-expressed receptors with EGF during 
this time interval might well enhance DNA synthesis further.

Our results indicate, however, that the DNA synthetic response within the first 24 hours is not mediated by EGF, as an anti-EGF antibody had effects similar to non-specific IgG, and did not prevent proliferation. The difference between the effect of anti-EGF antibody and non-specific IgG was small, and did not reach statistical significance. Our data may indicate that the predominant stimulus to hepatic regeneration at this time is some other growth factor interaction receptor, and indeed we and others have produced evidence for the early involvement of HGF in liver regeneration within a few hours of partial hepatectomy. ${ }^{31} \mathrm{HGF}$, however, does not interact with the EGF receptor, and explanations are required for the rapid down regulation that leads to a $50 \%$ reduction in the numbers of the EGF receptor at this time. The data reported here are compatible with the suggestion that locally generated TGF- $\alpha$ is the natural mediator of this process. ${ }^{721}$ There may, in addition, be some effect of EGF, as small amounts are present in the circulation or may be released from platelets at this time. ${ }^{12}$ The data presented here cannot exclude this possibility, as in a study with larger numbers of animals a statistically significant difference between the effects of anti-EGF and normal IgG might have emerged. The data do, however, indicate that EGF is not the predominant growth factor relevant at this time. The data also highlight that at the time of initiation of DNA synthesis after partial hepatectomy the process can be partially reduced by the administration of rabbit IgG and emphasise the importance of using appropriate controls in experiments of this type.

DV was the recipient of a Medical Research Council Studentship

1 Alison MR. Regulation of hepatic growth. Physiol Rev 1986; 66: 499-541.

2 Michalopoulos GK. Liver regeneration: molecular mechanisms of growth control. FASEB $71990 ; 4: 176-87$.

3 Selden C, Johnstone R, Darby H, Gupta S, Hodgson HJF. Human serum does contain a high molecular weight hepatocyte growth factor: studies pre-and post-hepatic resection. Biochem Biophys Res Commun 1986; 139: 361-6.

4 Nakamura T, Nawa K, Ichihara H, Kaise N, Nishino T. Purification and subunit structure of hepatocyte growth factor from rat platelets. FEBS Lett 1987; 224: 311-6.

5 Zarnegar R, Michalopoulos G. Purification and biological characterization of human hepatopoietin $\mathrm{A}$, a polypeptide growth factor for hepatocytes. Cancer Res 1989; 49: $3314-20$.

6 Kan M, Huang J, Mansson P-E, Yasumitsu H, Carr B McKeehan WL. Heparin-binding growth factor type 1 (acidic fibroblast growth factor): a potential biphasic autocrine and paracrine regulator of hepatocyte regeneration. crine and paracrine regulator of hepatocyte
7 Mead JE, Fausto N. Transforming growth factor- $\iota$ may be a physiological regulator of liver regeneration by means of an autocrine mechanism. Proc Natl Acad Sci USA 1989; 86. 1558-62.

8 LaBrecque DR, Steele G, Fogerty S, Wilson M, Barton J. Purification and physical-chemical characterization of hepatic stimulator substance. Hepatology 1987; 7: 100-6

9 Michalopoulos G, Houck KA, Dolan ML, Luetteke NC. Control of hepatocyte replication by two serum growth factors. Cancer Res 1984; 44: 4414-9.

10 McGowen JA, Strain AJ, Bucher NLR. DNA synthesis in primary cultures of adult rat hepatocytes in a defined medium: effect of epidermal growth factor, insulin, medium: effect of epidermal growth factor, insulin,

11 Earp HS, O'Keefe EJ. Epidermal growth factor receptor number decreases during rat liver regeneration. $\mathcal{F}$ Clin Invest $1981 ; 67: 1580-3$.

12 Marti U, Burwen SJ, Jones AL. Biological effects of epiderma growth factor, with emphasis on the gastrointestinal tract and liver: an update. Hepatology 1989; 39: 126-38.

13 Ullrich A, Schlessinger J. Signal transduction by receptors with tyrosine kinase activity. Cell 1990; 61: 203-12.

14 St. Hilaire RJ, Hradek GT, Jones AL. Hepatic sequestration and biliary secretion of epidermal growth factor (EGF): evidence for a high capacity uptake system. Proc Natl Acad Sci USA 1983; 80: 3797-801.

15 Fabrikant JI. Kinetic analysis of hepatic regeneration. Growth 1967; 31:311-5.

16 Grisham JW. A morphologic study of deoxyribonucleic acid synthesis and cell proliferation in regenerating rat liver; autoradiography with thymidine- ${ }^{-} \mathrm{H}$. Cancer Res 1962; 22: $842-9$.

17 Raper SE, Burwen SJ, Barker ME, Jones AL. Translocation of epidermal growth factor to the hepatocyte nucleus during rat liver regeneration. Gastroenterology 1987; 92: 1243-50.

18 Wollenberg GK, Harris L, Farber E, Hayes MA. Inverse relationship between epidermal growth factor induced proliferation and expression of high affinity surface epidermal growth factor receptors in rat hepatocytes. Lab Invest 1989; 60: 254-9.

19 Skov Olsen P, Boesby S, Kirkegaard P, Therkelsen K, Almdal $\mathrm{T}$, Poulsen SS, et al. Influence of epidermal growth factor on liver regeneration after partial hepatectomy in rats. Hepatology 1988; 8: 992-6.

20 Rall LB, Scott J, Bell GI, Crawford RJ, Penschow JD, Niall HD, et al. Mouse prepro-epidermal growth factor synthesis by kidney and other tissue. Nature $1985 ; 313: 228-31$.

21 Gruppuso PA, Mead JE, Fausto N. Transforming growth factor receptors in liver regeneration following partial hepatectomy in the rat. Cancer Res 1990; 50: 1464-9.

22 Yamada $H$, Hughes RV, Gove CB, Williams R. Effect of fulminant hepatitis serum in hepatic DNA synthesis in normal and partial hepatectomized rats. Eur $\mathcal{f}$ Gastroenterol Hepatology (in press).

23 Higgins GM, Anderson RM. Experimental pathology of the liver: restoration of liver of white rat following partial surgical removal. Arch Pathol 1931; 12: 186-202.

24 Moore JR. Purification and partial characterization of epidermal growth factor isolated from the male rat submaxillary gland. Arch Biochem Biophys 1978; 189: 1-7.

25 Schacterle GR, Pollack RL. A simplified method for quantitative assay of small amounts of protein in biological material. Anal Biochem 1973; 51:654-5.

26 Berry MN, Friend DS. High vield preparation of isolated rat liver parenchymal cells: a biochemical and fine structural liver parenchymal cells: a biochemich

27 Selden C, Hodgson HJF. Further characterisation of hepatotropin, a high molecular weight hepatotropic factor in rat serum $f$ Hepat 1989. 9: 167-76.

28 Munro HN, Fleck A. The determination of nucleic acids. Methods Biochem Anal 1966; 14: 113-76.

29 Talarico KS, Feller DD, Neville ED. Mitotic responses to various dietary conditions in normal and regenerating liver. Proc Soc Exp Biol Med 1971; 136: 381-4.

30 Stirling GA, Bourne LD, Marsh T. Effect of protein deprivation and reduced diet on the regenerating rat liver. $B r \mathcal{F} E \times p$ Pathol 1975; 56: 502-9.

31 Selden AC, Jones M, Wade D, Hodgson HJF. Hepatotropin mRNA expression in human foetal liver development and in liver regeneration. FEBS Letts 1990; 270: 81-4. 